\title{
Kesadaran Multikultural dan Kewirausahaan Masyarakat Desa (Kasus Desa Wisata Batuan, Bali)
}

\author{
Solihin dan Kanah \\ Jurusan Pariwisata, Politeknik Negeri Bali \\ email: solihinmoelyadi@gmail.com; kanah@pnb.ac.id
}

\begin{abstract}
Cultural tourism of Bali was supported by the existence of tourist objects or village activities, including the existence of the tourist village of Batuan, Sukawati, Gianyar that was flooded by tourists. This paper discusses the existence of tourist attraction at 'Pura Batuan' as multicultural education and growing entrepreneurship of the local people around the tourist object of "Pura Desa Batuan". The research data was collected through observation, document study and interviews with 8 informants: visitor and top leader of Batuan Village and researcher of Balinese culture. Data analysis was carried out descriptively, qualitatively by applying stakeholder and cultural commodification theory. The results of the study show that the cultural heritage of Pura Desa Batuan had become part of the main tourist attraction in the tourist village of Batuan, Sukawati, Gianyar Regency which attracts tourists. Its existence has become a vehicle for multicultural education, strengthening the cultural traditions of the people and entrepreneurship of the Balinese people in the local village.
\end{abstract}

Keywords: Tourism Village of Batuan, multicultural education and entrepreneurship.

\section{PENDAHULUAN}

Seperti yang digariskan dalam Peraturan Daerah Provinsi Bali No 2 tahun 2012, orientasi pembangunan pariwisata di Bali adalah pariwisata budaya, yakni pariwisata yang bertumpu pada kebudayaan Bali (yang dijiwai oleh Agama Hindu) sebagai bagian kebudayaan nasional yang berdasarkan Pancasila. Setiap langkah dan gerak dalam kerangka pengembangan pariwisata secara normatif diharapkan tetap bertumpu pada kebudayaan Bali.

Visi pembangunan pariwisata Bali adalah "Terwujudnya pariwisata budaya yang berkualitas, berkelanjutan dan mempunyai daya saing berdasarkan tri hita karana". Visi ini kemudian dijabarkan ke dalam beberapa misi, meliputi: (1) mewujudkan pariwisata budaya berbasis kerakyatan, (2) mewujudkan profesionalisme pengelolaan kepariwisataan, dan (3) mewujudkan pelayanan yang baik dibidang kepariwisataan. Visi-misi ini lebih lanjut dibarkan menjadi empat program utama Dinas Pariwisata Bali, yaitu pengembangan: (a) destinasi pariwisata, (b) pemasaran pariwisata, (c) industri pariwisata, dan (d) kelembagaan pariwisaata (Dispar Bali, 2018). 
Sebagai destinasi utama pariwisata Indonesia, Bali sejak tahun 1920-an telah dikunjungi wisatawan. Bandara Internasional Ngurah Rai semakin sibuk. Dalam satu tahun, Bandara Udara Internasional Ngurah Rai melayani sebanyak lebih dari 70.000 penerbangan domestik dan lebih dari 50.000 penerbangan internasional. Gambaran kunjungan wisawan mancanegara ke Indonesia ditunjukkan pada Gambar 1.

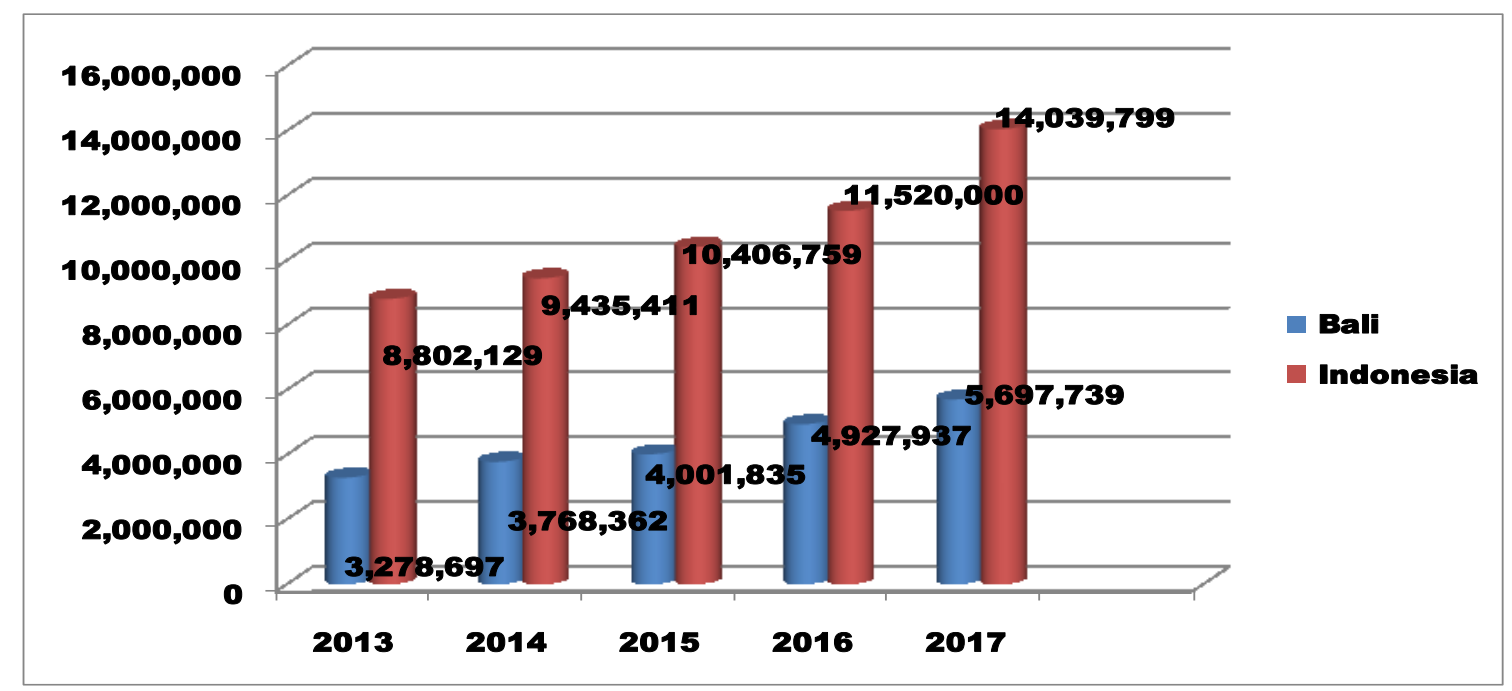

Gambar 1: Kunjungan Wisman ke Bali dan Indonesia (2013 - 2017) (Sumber: Disparda Bali, 2018)

Dinamika pariwisata budaya Bali telah menumbuhkan kegiatan wisata di beberapa desa wisata yang memiliki objek wisata pura, termasuk objek wisata Pura Tanah Lot Tabanan, objek wisata Pura Ulu Watu, Badung Selatan, dan objek wisata Pura Desa Adat Batuan, Kecamatan Sukawati, Kabupaten Gianyar. Objek wisata Pura Desa Adat Batuan telah menjadi kegiatan utama bagi dersa wisata setempat. Sebagai bagian dari pusaka budaya, objek wisata Pura Desa Batuan terdapat seni arca abad VII-X Masehi, seni arca Bali abad X - XIV Masehi serta tradisi budaya masyarakat setempat. Objek wisata Pura Desa Batuan memperoleh sambutan positif wisawan. Terdapat kelompok wisatawan, baik domestik maupun mancanegara mencari sesuatu yang tertarik terhadap peninggalan situs arkeologis sebagai bagian dari pusaka (Ardika, 2007: 47).

Sejalan dinamika kepariwisataan Bali, sejak dekade 1980-an objek wisata Pura Batuan terus dikembangkan dan direnovasi secara bertahap, baik dari segi sarana, objek dan atraksi wisata yang disajikan bagi wisatawan, maupun dari segi manajemen serta stakeholders yang terlibat di dalamnya. Perkembangan objek wisata Pura Desa Batuan tetap menunjang pembangunan pariwisata Bali yang berkelanjutan, yakni pariwisata yang mempertimbangan aspek mutu sumber daya alam dan budaya, 
meningkatnya kesejahteraan masyarakat lokal, dan terwujudnya kepuasan wisatawan (Ardika, 2007:164).

Dalam aktivitas pariwisata, terjadi hubungan timbal antara wisatawan dan masyarakat setempat. Masyarakat lokal mendapatkan berkah ekonomi, sementara wisatawan memperoleh pengetahuan tentang budaya masyarakat lokal yang dikunjungi. Terdapat pendidikan multikultural dalam aktivitas pariwisata budaya, sebagaimana yang dijumpai dalam kegiatan wisata pada objek wisata Pura Batuan, Sukawati.

Tulisan ini membahas eksistensi objek wisata Pura Batuan

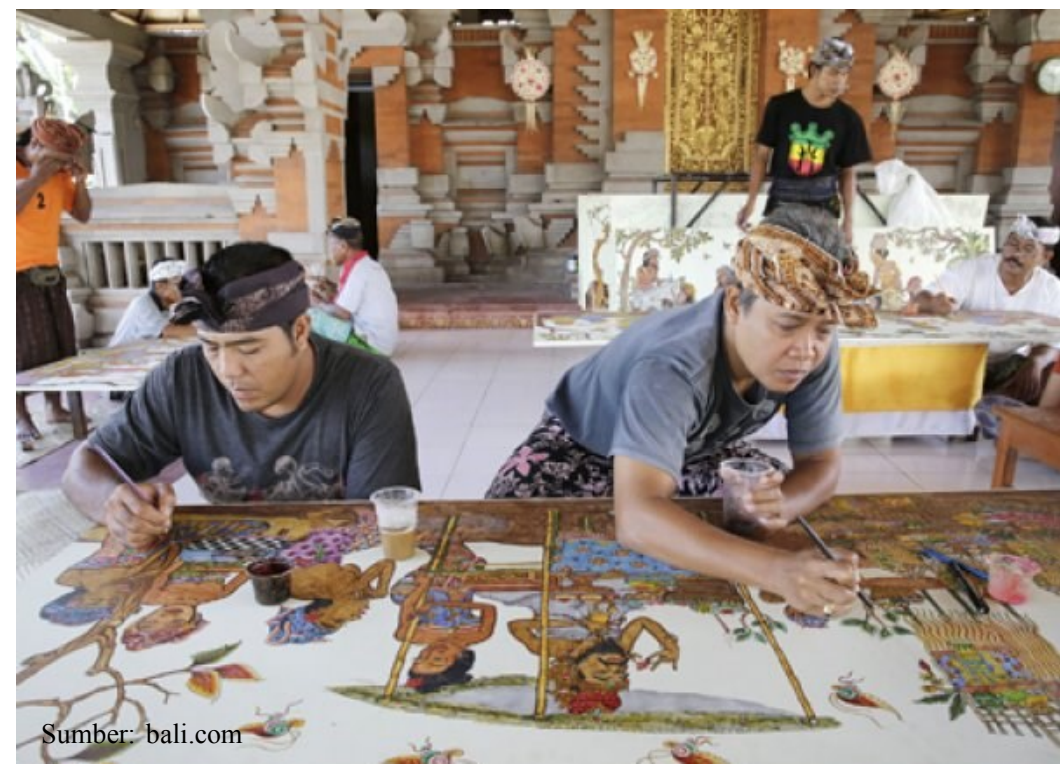
sebagai wahana pendidikan tentang pluralitas budaya (multikultural), dan menumbuhkan wirausaha masyarakat di sekitar objek wisata Pura Desa Batuan. Makalah ini merupakan hasil penelitian kualitatif. Proses pengumpulan data dilakukan dengan observasi, studi dokumen dan wawancara dengan 8 informan, yakni wisatawan, pengelola Pura Desa Batuan, serta pengamat budaya Bali. Analisis data dilakukan secara deskriptif-kualitatif dengan menerapkan teori stakeholders dan teori komodifikasi budaya. Publikasi ini diharapkan mampu memperkenalkan kepada pembaca (masyarakat luas) tentang keberadaan objek dan atraksi wisata di Pura desa Batuan sebagai wahana pendidikan pluralitas budaya (multikultural) sekaligus untuk menumbuhkan kreatifitas seni-budaya dan wirausaha rakyat Bali.

\section{PENDIDIKAN MULTIKULTURAL DI DESA WISATA BATUAN}

Jenis pariwisat yang ditumbuhkembangkan di Bali adalah pariwisata budaya. Pariwisata budaya mencakup semua jenis pariwisata yang menonjolkan aspek kebudayaan, baik dalam pengertian ideofact, sociofact, dan artifact. Obyek-obyek budaya atau bangunan bersejarah merupakan bagian dari wisata budaya. Pusaka budaya yang berbentuk peninggalan-peninggalan arkeolog dapat dimanfaatkan untuk kepentingan pengembangan pariwisata. Komponen budaya dapat dijadikan produk untuk dikonsumsi oleh para wisatawan. Komponen budaya tersebut meliputi: (1) situs arkeolog dan museum, (2) arsitektur, (3) seni (art), patung, kerajinan, festival budaya, 
(4) musik dan tari, (5) drama (teater, film), (6) bahasa dan sastra, (7) upacara agama, dan (8) budaya tradisional (Ardika, 2004: 23).

Dalam praktik sehari-hari, objek wisata Pura Desa Batuan telah menjadi media pendidikan tentang adanya pluralitas budaya. Hal ini nampak dari pemanfaatannya sebagai: (1) salah satu laboratorium sosial-budaya tentang masyarakat Bali; (2) sebagai media pendidikan tentang tri hita karana; (3) sebagai media pendidikan tentang multikultural.

Keberadaan objek wisata Pura Desa Batuan menjadi bagian dari laboratorium sosial-budaya tentang masyarakat Bali. Wisatawan akan disambut dengan ramah oleh masyarakat setempat. Wisatawan juga melihat beragam objek sosial-budaya masyarakat Bali yang ada di desa setempat, termasuk karya seni arsitektur, benda budaya, dan tradisi sosial-budaya Hindu masyarakat Bali. Wisatawan disuguhi panorama bangunan Pura Desa Batuan yang artistik dan megah. Sebagai salah satu Pura tertua yang ada di Pulau Dewata, Pura Desa Batuan dibangun pada 944 Çaka atau 1022 Masehi. Pura ini memiliki sejarah yang panjang, merupakanpeninggalan purbakala, yakni aneka jenis arca yaitu arca dwarapala, arca binatang, arca perwujudan, arca memegang ayam, lingga, dan lain sebagainya (Karmini, 2013).

Objek wisata budaya Pura Desa Batuan juga sebagai wahana pembelajaran tentang Tri Hita Karana (THK). Dengan dasar filosofi Tri Hita Karana, manusia (pawongan) dihadirkan selaras dengan lingkungan pura (palemahan) yang menyadari sebagai hamba Tuhan (Prahyangan). Hal ini sesuai pernyataan Capra (2002: 327) bahwa manusia hanyalah sebagai bagian dari makhluk hidup dan jaring-jaring kehidupan di lingkungannya. Masyarakat setempat tetap menjunjung tinggi filosofi THK ini. Mereka berupaya menjalani hidup dengan menjalin hubungan yang harmonis dengan Hyang Widi Wasa (parahyangan), menjaga hubungan harmonis dengan sesamanya (pawongan), serta menjaga keselarasan hidup dengan lingkungannya (palemahan).

Filosofi THK menjadi konsep dasar pariwisata budaya Bali. Secara konsepsional pariwisata budaya diharapkan menciptakan keserasian, keselarasan dan keseimbangan antara penyelenggaraan pariwisata dan kebudayaan Bali. Selain itu, mutu objek dan daya tarik wisata diharapkan dapat meningkat dan tetap lestari, serta mampu mempertahankan norma, nilai kebudayaan, agama dan menghindari pengaruh negatif pariwisata. Konsep ini selaras dengan paradigma baru yaitu pariwisata yang berkelanjutan yang berbasis masyarakat dan senantiasa memelihara mutu dan kelanjutan sumber daya alam, meningkatkan kesejahteraan masyarakat lokal dan 
terwujudnya keseimbangan antara sumbar daya alam dan budaya, kesejahteraan masyarakat lokal serta kepuasan wisatawan (Ardika, 2002).

Keberadaan objek wisata Pura Batuan juga sebagai wahana pendidikan tentang pluralitas budaya. Kegiatan seni-budaya seperti seni tari gambuh, seni lukis tradisional, seni tabuh, seni ukir pada waktu-waktu tertentu manfaatkan untuk menunjang atraksi wisata di Pura Desa Batuan, termasuk tarian sakral, yakni tarian Rejang Sutri dan Rejang Bogolan untuk penolak bala desa setempat. Tarian penolak bala ini dipentaskan setiap enam bulan sekali, tepatnya pada saat sasih (bulan) kelima kalender Bali (bulan November) sampai sasih kesangaatau kesembilan (bulan Maret).

Pura Desa Batuan telah menjadi bagian dari komodifikasi budaya, yakni objek wisata Pura batuan sengaja diproduksi, dipasarkan (didistribusikan) dan dikonsumsi. Komodifikasi adalah proses terjadinya perubahan barang atau layanan yang sebelumnya mengikuti aturan sosial non-pasar menjadi suatu subjek yang mengikuti aturan pasar (Gleik, 2002). Komodifikasi merupakan salah satu bentuk kapitalisme global mengakumulasi kapital, komodifikasi telah mentransformasi nilai guna menjadi nilai tukar yang sifatnya komersial (Ardono, 1979). Meminjam istilah Boudieu, kehidupan sehari-hari, upacara adat serta pusaka budaya Pura Desa Batuan telah menjadi modal budaya yang dijual kepada wisatawan yang datang untuk mendapatkan modal ekonomi. Selanjutnya modal ekonomi yang diperoleh dari lapangan kehidupan wisata itu mampu memperkuat kehidupan adat dan agama masyarakat setempat.

Atraksi seni-budaya ini sengaja disunguhkan kepada para turis sebagai media hiburan sekaligus sebagai wahana pendidikan multikultural. Pendidikan multikultural merupakan sebuah pendekatan pengajaran dan pembelajaran yang didasarkan atas nilai-nilai demokratis yang mendorong berkembangnya pluralisme budaya. Pendidikan multikultural merupakan sebuah komitmen untuk menumbuhkan pemahaman tentang kelompok-kelompok etnik dan memberangus praktik-praktik penindasan.

Pendidikan multikultural sarat dengan penghargaan, penghormatan dan kebersamaan dalam suatu komunitas yang majemuk. Pendidikan multibudaya meliputi sebuah pemahaman, penghargaan dan penilaian atas budaya seseorang, dan sebuah penghormatan dan keingintahuan tentang budaya etnis orang lain. la meliputi penilaian terhadap kebudayaan-kebudayaan orang lain, bukan dalam arti menyetujui seluruh aspek dari kebudayaan-kebudayaan tersebut, melainkan mencoba melihat bagaimana kebudayaan tertentu dapat mengekspresikan nilai bagi anggota-anggotanya sendiri. Dalam kaitan ini, secara umum ada tiga hal yang perlu ditekankan dalam pendidkan multikultural, yaitu: (1) menegaskan identitas kultural seseorang, mempelajari dan 
menilai warisan budaya seseorang; (2) menghormati dan berkeinginan untuk memahami serta belajar tentang etnik/kebudayaan-kebudayaan selain kebudayaannya; dan (3) menilai dan merasa senang dengan perbedaan kebudayaan itu sendiri; yaitu memandang keberadaan dari kelompok-kelompok budaya yang berbeda dalam masyarakat seseorang sebagai kebaikan yang positif untuk dihargai dan dipelihara (Blum, 2001: 19).

Secara umum wisatawan memiliki kesan positif terhadap objek wisata di Pura Batuan. Kesan dan sikap positif wisatawan terhadap tradisi dan upacara keagamaan masyarakat Hindu Bali tersebut merupakan bentuk mereka yang respek terhadap budaya Bali. Pengakuan dan penghormatan terhadap kepercayaan dan keyakinan umat agama lain merupakan bentuk respek mereka terhadap pluralism budaya dan agama.Dalam kaitan ini, pemerhati masalah adat budaya Bali, Sukanata (57 tahun) memberikan komentar sebagai berikut:

"Pesona Bali tak hanya sebatas panorama indah pegunungan atau persawahan yang asri, namun tradisi masyarakat Hindu Bali, termasuk pelaksanaan upacara di pura-pura amat diperhatikan oleh wisatawan. Di antara tamu (wisatawan) itu, ada yang ingin mempelajari lebih jauh tentang tradisi Bali yang mereka lihat (wawancara, 1 Juni 2018)."

Rangkaian pelaksanaan upacara adat masyarakat Hindu Bali telah dijadikan menu atraksi wisata di Desa Batuan. Atraksi wisata di Pura Desa Batuan telah berhasil memikat wisatawan, dan mampu menggugah kesadaran multikultural mereka. Kesadaran multikultural ini penting dalam pergaulan antar budaya yang perlu sikap saling menghormati satu sama lain. Kesadaran multikultural juga menjunjung tinggi pentingnya sikap dan perilaku toleransi dalam kehidupan bangsa Indonesia yang multi ethnik ini. Sikap toleransi ini penting dalam membina kehidupan bangsa yang multikultural. Keberagaman budaya masyarakat nusantara ini merupakan konsekwensi keragaman budaya, etnis, suku dan aliran atau agama (Maslikhah, 2007: 748).

Keberagaman budaya di Indonesia yang tercermin dalam kehidupan masyarakat Bali yang ada di sekitar Pura Desa Batuan adalah kenyataan historis dan sosial yang nyata. Keunikan budaya yang beragam tersebut memberikan implikasi pola pikir, tingkah laku dan karakter pribadi masing-masing sebagai sebuah tradisi yang hidup dalam masyarakat dan daerah. Keragaman tradisi budaya, seperti yang dimiliki oleh masyarakat Bali di Desa Wisata Batuan telah menjadi media pendidikan multikultural yang penting untuk memperkokoh rasa persaudaraan dan kemanusiaan masyarakat nusantara yang multi ethnik ini. Baik tamu (wisatawan) maupun warga desa Batuan selaku tuan rumah akan saling belajar akan adanya multi tradisi, multi 
budaya di muka bumi ini. Hal ini, secara sadar dan tidak sadar akan menumbuhkan rasa saling empati seseorang dengan sesamanya.

Pergumulan antar budaya memberikan peluang konflik manakala tidak terjadi saling memahami dan menghormati satu sama lain. Proses untuk meminimalisir konflik inilah memerlukan upaya pendidikan yang berwawasan multikultural dalam rangka pemberdayaan masyarakat yang majemuk dan heterogen agar saling memahami dan menghormati serta membentuk karakter yang terbuka terhadap perbedaan (Tilaar, 2004: 9). Pluralitas budaya, sebagaimana terdapat di Indonesia, menempatkan pendidikan Multikultural menjadi sesuatu yang urgen (Yaqin, 2005: 3). Kesadaran multibudaya dan toleransi semakin penting untuk memantapkan integrasi bangsa, dan mampu menyetop segala bentuk intoleransi yang nampak muncul ke permukaan dalam kehidupan bangsa Indonesia yang sedang menyiapkan pentas demokrasi (pemilihan legislatif dan presiden) pada tahun 2019.

\section{WIRAUSAHA RAKYAT BALI DI DESA WISATA BATUAN}

Objek wisata utama Desa Batuan, yakni Pura Desa Batuan berada di Dusun Tengah, Desa Batuan, Kecamatan Sukawati, Kabupaten Gianyar. Objek wisata ini berjarak sekitar 16 kilometer ke arah timur dari Kota Denpasar atau 13 kilometer sebelah barat kota Gianyar. Letak Pura Batuan yang strategis, mudah dijangkau dari Kota Denpasar. Objek wisata yang berupa bangunan pura ini menjadi objek wisata pilihan yang dikunjungi wisatawan, baik wisatawan domestik maupun wisatawan asing. Setiap hari, sekitar 3 sampai 10 bus rombongan wisatawan berkunjung ke komplek wisata Pura Desa Batuan. Rombongan bus itu mengangkut tamu yang berasal dari berbagai daerah Pulau Jawa, juga rombingan wisatawan asing, termasuk dari China dan kawasan Asia lainnya.

Desa wisata Batuan banyak dikenal wisatawan karena desa wisata ini sengaja dikelola secara professional oleh jaringan pelaku wisata yang melibatkan desa adat setempat. Dinas Pariwisata Kabupaten Gianyar, para pelaku wisata, termasuk guide, jaringan biro perjalanan dan stakeholders lainnya secara aktif turut memasarkan keberadaan objek dan atraksi wisata di Pura Desa Batuan. Desa Adat Batuan secara aktif mengelola situs arkeologis Pura Batuan serta melaksanakan berbagai macam upacara adat untuk diseguhkan kepada wisatawan yang datang.

Pemeliharaan Pura Desa batuan sebagai objek wisata, antara lain disertai dengan upaya pemugaran Pura Desa Batuan sebagai objek wisata sejak tahun 1980an. Pemugaran bangunan Pura Desa Batuan dilakukan karena adanya tuntutan 
berbagai pihak. Secara internal renovasi objek wisata Pura batuan dikehendaki oleh masyarakat adat lokal, secara eksternal hal itu dilakukan sebagai respon atas tuntutan terhadap perkembangan pariwisata Bali pada umumnya.

Pergeseran fungsi Pura terjadi mengikuti perkembangan dalam pengelolaannya. Pertama, apabila semula fungsi Pura Desa Batuan hanya untuk tempat upacara adat/agama (Hindu), maka sejak dekade 1980-an Pura Desa Batuan dikembangkan menjadi objek wisata. Semula, aktivitas adat dan upacara hanya diorientasikan untuk kepentingan agama, namun tradisi masyarakat Desa Batuan itu sengaja dilakukan sebagai atraksi budaya untuk pariwisata. Wisatawan sengaja disuguhi tontonan berupa kegiatan tradisi seperti upacara di pura, upacara pembakaran mayat sesuai adat Bali. Kedua, jika sebelumnya pengelolaan Pura Batuan dilakukan oleh masyarakat adat setempat, maka setelah dijadikan objek wisata, pengelolaan Pura Batuan pasca dekade 1980-an telah melibatkan berbagai pihak, termasuk pelaku saja wisata dan wisatawan yang berkunjung. Ketiga, terjadi proses renovasi bangunan Pura Desa Batuan dan sekitarnya sebagai konsekwensi atas pengembangan situs budaya ini sebagai objek wisata. Dalam dekade 1990-an, objek wisata Pura Desa Batuan direnovasi secara besar-besaran, seiring semakin banyaknya kunjungan wisatawan ke Pura tersebut. Selama decade 1990-an Pura Desa Batuan dimodifikasi dengan pola tri mandala, yaitu yang terdiri atas tiga halaman, yaitu jeroan, halaman tengah dan halaman luar. Pertamanan di depan Pura juga ditata sehingga menambah kenyamanan, kesejukan, dan keindahan areal Pura Desa Batuan. Para pengunjung dapat memanfaatkan pertamanan untuk beristirahat atau melepas lelah setelah bersembahyang atau sekedar berwisata religius bagi wisatawan.

Selain itu, jaringan pemasaran objek wisata Pura Desa Batuan semakin berkembang sejak dekade 2000-an. Objek wisata desa Batuan memasuki pasar global yang melibatkan penyedia jasa transportasi/biro perjalanan, jasa akomodasi dan jaringan pemasaran jasa wisata baik lokal, nasional maupun internasional. Pemasaran objek wisata Pura Desa Batuan menjadi semakin efektif di era teknologi internet dewasa ini (Karmini, 2013).

Pariwisata telah mempengaruhi berbagai segi kehidupan masyarakat Bali, baik positif maupun negatif. Menurut Milman (dalam Pitana, 1999: 118), pengaruh positif pariwisata antara lain adalah adanya pelestarian budaya masyarakat lokal seperti kegiatan keagamaan, adat istiadat, dan tradisi, dampak terjadinya transformasi norma (nilai, moral, peranan seks), dan dampak modifikasi pola konsumsi masyarakat 
setempat, serta dampak lingkungan (pencemaran, polusi, kemacetan lalu lintas) dan sebagainya. Sebagaimana yang terlihat dalam kehidupan masyarakat Pura Desa Batuan, pengaruh positif dari kegiatan pariwisata terhadap budaya masyarakat lokal antara lain; munculnya kreativitas dan inovasi budaya, akulturasi budaya, dan revitalisasi budaya. Sedangkan pengaruh negatif yang sering dikawatirkan terdapat budaya masyarakat lokal antara lain; proses komodifikasi, peniruan budaya (Ardika 2003: 25).

Aktivitas wisata di Pura Batuan telah merangsang tumbuhnya berbagai macam kegiatan ekonomi dan kreatifitas kerajinan rakyat setempat. Berbagai cendera mata, termasuk tas, dompet, kain pantai, patung mini sengaja diproduksi dan dipasarkan langsung melalui pedagang kaki lima dan toko-toko seni di sekitar Desa batuan, Sukawati Gianyar. Salah satu karya seni yang unik diproduksi oleh seniman setempat adalah patung ogoh-ogoh mini. Sebagai karya seni-budaya rakyat Bali, ogoh-ogoh mini juga dipasarkan di berbagai toko souvenir di Kota Denpasar dan kabupaten lainnya di Bali (Sadiartha, 2016).

Berbagai jenis wirausaha tumbuh berkembang sejalan dengan dinamika pariwisata di Desa Batuan, Sukawati. Di antaranya adalah wirausaha warung makan, toko souvenir, toko yang menjual kerajinan alat-alat upacara, pemandu wisata, dan sebagainya. Berbagai jenis wirausaha ini jelas memberikan kontribusi yang berarti bagi perekonomian masyarakat lokal. Pariwisata telah mempengaruhi jiwa kewirausahaan rakyat Bali seperti yang jelas terjadi di Desa wisata Batuan, Sukawati. Seperti kata Pitana (2005: 110), sektor pariwisata memang memiliki multiplier effect, yakni angka pengganda melebihi angka pengganda kegiatan ekonomi lainnya.

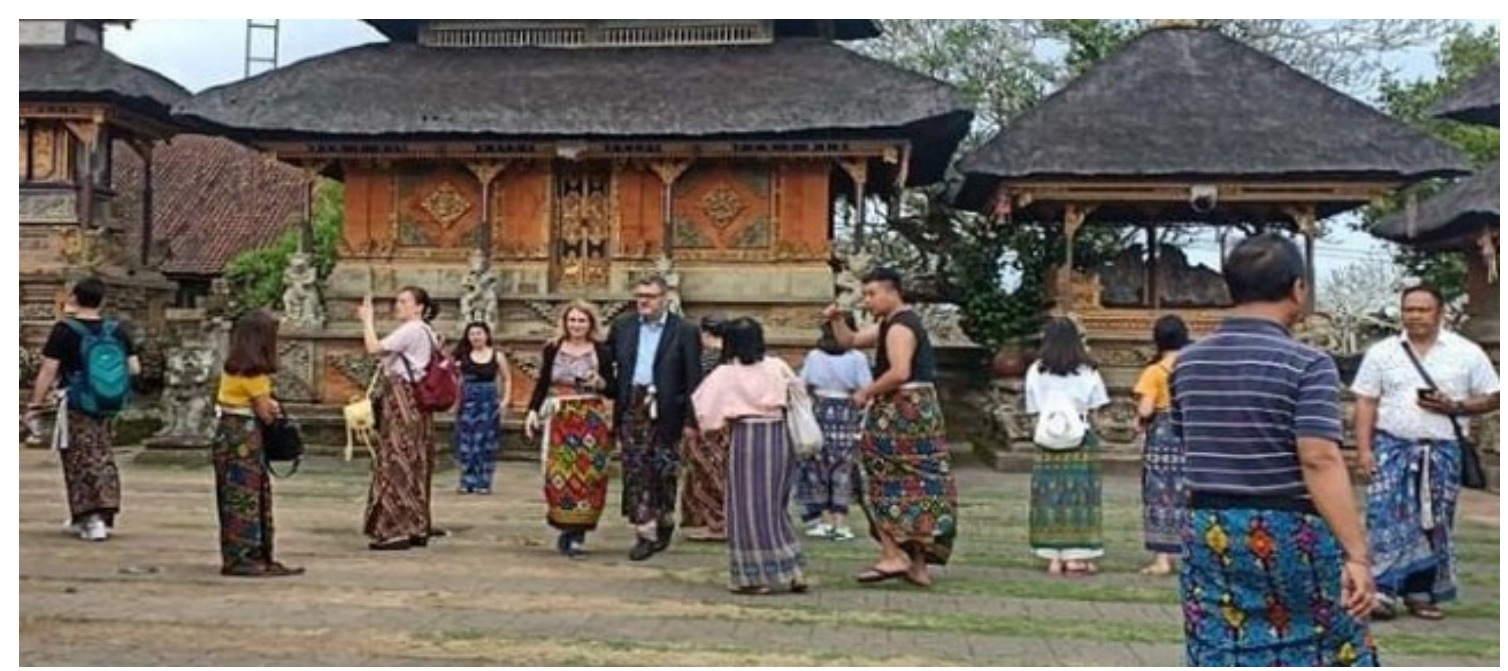

Gambar 2: Wisatawan di Pura Batuan

(Sumber: http://www.balipost.com/news/2018). 
Menurut pemuka masyarakat Desa Batuan, Nyoman Marsa (60 tahun), setiap hari sekitar 400 orang wisatawan yang mengunjungi Pura Desa Batuan. Mayoritas mereka adalah wisatawan asing, sedangkan tamu domestik hanya sekitar $10 \%-20 \%$. Setiap wisatawan memberikan donasi minimal 10 ribu rupiah. Tiap hari rata-rata donasi yang terkumpul sebanyak tiga sampai lima juta rupiah; tiap bulan ratarata Rp. 12 juta. Sebagian besar hasil donasi ini digunakan untuk pemeliharan pura dan mendukung kegiatan upacara adat, sebagian kecil lainnya untuk upah petugas yang melayani kegiatan pariwisata di Pura Desa Batuan (Karmini, 2013).

luran atau donasi wisatawan tentu bermanfaat bagi pengelola Pura Desa Batuan dan desa adat setempat. Selain untuk operasionalisasi penyelenggara kegiatan wisata setempat, termasuk untuk memberikan honor bagi petugas parkir kendaraan dan juru arah (guide) wisata adat Desa Batuan, donasi yang diperoleh dari wisatawan juga berfungsi untuk pemeliharaan pura, mendukung pelaksanaan upacara adat, serta untuk mendukung kegiatan seni-budaya di Pura Desa Batuan.

Kunjungan wisata ke objek wisata Pura Batuan telah menjadi berkah bagi warga setempat. Wirausaha rakyat bisa ditumbuhkan. Sebagian warga membuka kios makanan-minuman, sebagian lainnya membuka kios cendera mata, sebagian lainnya terlibat dalam layanan jasa wisata termasuk menjadi pemandu wisata dan pegawai biro perjalanan wisata. Keberadaan Pura Desa Batuan telah menjadi komoditas wisata yang menguntungkan masyarakat lokal. Kehadiran wisatawan telah menumbuhkan wirausaha rakyat dan mendukung penguatan tradisi masyarakat Desa Adat Batuan.

\section{SIMPULAN DAN SARAN}

Pusaka budaya Pura Desa Batuan telah menjadi bagian dari objek wisata utama di Desa wisata Batuan, Kecamatan Sukawati, Kabupaten Gianyar. Keberadaan objek dan atraksi seni-budaya di lingkungan Pura Desa Batuan telah memikat sebagian wisatawan yang berkunjung di Bali. Keberadaanya telah menjadi wahana pendidikan tentang pluralitas budaya (multikultural), memperkokoh tradisi budaya masyarakat dan membangkikan kehidupan sosial-ekonomi masyarakat desa setempat. Aktivitas wisata di Pura Desa Desa Batuan yang mampu membangkitkan wirausaha dan memperkuat tradisi budaya masyarakat Bali setempat serta membangkitkan kesadaran multikultural ini perlu terus dipertahankan dan dikembangkan. 


\section{DAFTAR PUSTAKA}

Adorno dan Horkheimer. 1979. The Culture Industry Enlightenment as Mass Deception London: Verso.

Ardika, I Wayan. 2003. Pariwisata Budaya Berkelanjutan Refleksi dan Harapan di Tengah Perkembangan Global. Denpasar. PS Kajian Pariwisata, Universitas Udayana.

Ardika, I Wayan.2004. "Pariwisata Bali: Membangun Pariwisata Budaya dan Mengendalikan Budaya Pariwisata" dalam Bali Menuju Jagadhita, Aneka Persepktif. Denpasar: Pustaka Bali Post.

Ardika, I Wayan. 2007. Pusaka Budaya dan Pariwisata. Denpasar: Pustaka Larasan.

Astajaya, Manik. 2018. "Pura Desa Dan Puseh Batuan Dikunjungi Dua Ribu Lebih Wisatawan", http://www.balipost.com/news/2018/09/03/54489/Pura-Desa-dan-PusehBatuan...html, diakses Senin, 3 September 2018 pukul 09:03:15.

Blum, Lawrence. 2001. "Antirasisme, Multikulturalisme, dan Komunitas Antar Ras, Tiga Nilai Yang bersifat Mendidik Bagi Sebuah Masyarakat Multikultural" dalam Larry May, dan Shari Colins-Chobanian, Etika Terapan: Sebuah Pendekatan Multikultural, Alih Bahasa: Sinta Carolina dan Dadang Rusbiantoro. Yogyakarta: Tiara Wacana.

Capra, F. 2002. Jaring-jaring Kehidupan: Visi Baru Epistemologi dan. Kehidupan. Terjemahan oleh Saut Pasaribu. Yogyakarta: Fajar Pustaka.

Gleick, Peter H. et al. 2002. The New Economy of Water: The Risk and Benefits of Globalization and Privatization of Fresh Water. California: Pasific Institute.

Karmini, Ni Wayan. 2013. Optimalisasi Pengembangan Obyek Wisata Pura Desa Batuan, Sukawati, Gianyar. Denpasar: Universitas Hindu Indonesia.

Maslikhah. 2007. Quo Vadis Pendidikan Multikultural: Reconstruksi Sistem Pendidikan Berbasis Kebangsaan. Surabaya: JP Books.

Pitana, I Gde. 1999. Pelangi Pariwisata Bali, Kajian Aspek Sosial Budaya Kepariwisataan Bali di Penghujung Abad. Denpasar: Bali Post.

Pitana, I Gde dan Putu G Gayatri. 2005. Sosiologi Pariwisata. Yogyakarta. Andi

Peraturan Daerah Provinsi Bali. Nomor 2 Tahun 2012 tentang. Kepariwisataan Budaya Bali

Sadiartha, Anak Agung. 2016. Budaya Entrepreneurship dalam Tradisi Masyarakat Hindu Bali. Denpasar: Percetakan Bali

Tilaar, H.A.R. 2004. Multikulturalisme: Tantangan-tantangan Global Masa Depan dalam Transformasi Pendidikan Nasional. Jakarta: Grasindo.

Yaqin, M. Ainul. 2005. Pendidikan Multikultural: Cross-Cultural Understanding untuk Demokrasi dan Keadilan. Yogyakarta: Pilar Media 
